\title{
Nutrition-sensitive agriculture and the promotion of food and nutrition sovereignty and security in Brazil
}

\author{
Agricultura sensível à nutrição e a promoção da soberania \\ e da segurança alimentar e nutricional no Brasil
}

\author{
Renato Sergio Maluf ${ }^{1}$ \\ Luciene Burlandy ${ }^{2}$ \\ Mariana Santarelli ${ }^{3}$ \\ Vanessa Schottz ${ }^{4}$ \\ Juliana Simões Speranza ${ }^{3}$
}

${ }^{1}$ Centro de Referência em Segurança Alimentar e

Nutricional, Universidade Federal Rural do Rio de Janeiro. Av. Presidente Vargas $417 / 8^{\circ}$, Centro. 20071-003 Rio de Janeiro RJ Brasil.

rsmaluf@gmail.com

${ }^{2}$ Universidade Federal

Fluminense.

${ }^{3}$ CERESAN/UFRRJ.

${ }^{4}$ Universidade Federal do

Rio de Janeiro.

\begin{abstract}
This paper explores the possibilities of the nutrition-sensitive agriculture approach in the context of the programs and actions towards promoting food and nutrition sovereignty and security in Brazil. To analyze the links between nutrition and agriculture, this paper presents the conceptual framework related to food and nutrition security, and stresses the correlations among concepts, institutional structures and program design in Brazil. Dominant models of food production and consumption are scrutinized in the light of these relationships. This paper also highlights differences amongst different ways to promote nutrition-sensitive agriculture through food-acquisition programs from family farmers, experiences in agro-ecology and bio-fortification programs. In the closing remarks, the paper draws some lessons learned from the Brazilian experience that highlight the advantages of family farming and rapid food production, distribution and consumption cycles in order to promote access to an affordable, diversified and more adequate diet in nutritional terms.

Key words Food and nutrition security, Food sovereignty, Agro-ecology, Family farming, Food policies
\end{abstract}

Resumo $O$ artigo explora as possibilidades da abordagem sobre agricultura sensivel à nutrição no contexto dos programas e ações de promoção da soberania e segurança alimentar e nutricional no Brasil. A análise dos elos entre agricultura e nutrição tem em conta o marco conceitual e suas correlações com as estruturas institucionais e o desenho dos programas nessa área no Brasil, especialmente com respeito aos modelos dominantes de produção e consumo de alimentos. O texto destaca também as diferenças entre os modos de promover uma agricultura sensivel à nutrição por meio dos programas de aquisição de alimentos dos agricultores familiares, experiências de agroecologia e programas de biofortificação. As considerações finais extraem lições da experiência brasileira quanto às vantagens da agricultura familiar, dos circuitos curtos de produção, distribuição e consumo e na promoção do acesso a uma dieta não custosa, diversificada e adequada em termos nutricionais. Palavras-chave Segurança alimentar e nutricional, Soberania alimentar, Agroecologia, Agricultura familiar, Políticas alimentares 


\section{Introduction}

This paper aims at stressing the possibilities of the nutrition-sensitive agriculture (NSA) approach in the context of recent developments in Brazil related to food and nutrition sovereignty and security (FNSS) and the right to adequate food (RtF). For analysing the links between nutrition and agriculture, the methodology has, as its starting point, the conceptual framework related to food and nutrition security, and the correlations between concepts, institutional structures and programme design in Brazil. A comparative analysis was made of the Brazilian conceptual, political and institutional framework and three distinct approaches to NSA that has been developed internationally. This provides a benchmark for evaluating the possibilities of applying the NSA approach in this case. It is also assumed that concepts support social actors practices, as well as disputes in the political ground that affect expected outcomes in this field.

Secondary socio-economic and nutritional data have been collected to indicate the progress and challenges for the national policy. The process of data collection was based on a review of national and international studies on food and nutrition security, evaluation studies of federal programmes, documental analysis of policy proposals and federal legislation, and official documents of the National Council for Food and Nutrition Security (CONSEA) from 2003 to 2013.Empirical evidence was provided by discussing the possibilities and challenges to implementing an intersectoral and participatory perspective of three programs as well as agroecological experiences.

The paper is divided into four sections. First, conceptual and institutional matters related to FNSS and the RtF in Brazil and recent trends in socioeconomic and nutritional status. Secondly, main aspects of the relationship between agricultural models and access to adequate and healthy food. Thirdly, intersectoral programmes and initiatives related to FNSS and some experiences in bio-fortification. Fourthly, lessons learned from the Brazilian experience.

\section{Concepts and institutional frameworks}

An innovative approach to food and nutrition security and sovereignty (FNSS) has been developed in Brazil over the last 20 years as a social construction gathering a wide range of social actors. The perspective of linking agriculture and nutrition in the very conceptualization of FNSS as well as in the systemic and intersectoral institutional framework for policy making stands out among the outcomes of this construction ${ }^{1,2}$.

A national legislation determined the building up of the National System for Food and Nutrition Security (SISAN) aimed at promoting the RtF by implementing public policies for FNS. According to the law, food and nutrition security consists of realizing the right of all to regular and permanent access to good quality food, in sufficient quantity, without compromising the access to other essential needs, on the basis of food habits that promote health and respect cultural diversity and that are environmentally, culturally, economically and socially sustainable. The same law established that the realization of the human right to adequate food and the attainment of food and nutritional security require respect for sovereignty, which confers to countries primacy in their decisions regarding the production and consumption of food products ${ }^{3,4}$. The SISAN is comprised by: CONSEA, an intersectoral space with civil society representatives and government officials from 19 Ministries of State that discuss, design and evaluate programmes and actions related to FNS; Inter-Ministerial Chamber (CAISAN), a governmental body having the mission of coordinating actions among the 19 Ministries. Integrating nutrition into agricultural and rural development policies constitutes a permanent challenge in the agenda of CONSEA and CAISAN ${ }^{5}$.

Some of the key lessons learned from this process include: (a) the importance of participatory pacts related to concepts and principles; (b) the appropriateness of the systemic and intersectoral approach; (c) the existence of formal spaces of social dialogue; (d) the necessary practice of intersectoral coordination of public policies ${ }^{6}$.

Although Brazil is still a highly unequal country, there have recently been significant improvements in extreme poverty reduction and income distribution. Regarding malnutrition and infant mortality, Brazil also made recent outstanding improvements. Despite all these progress, Brazil is facing an increasing trend of overweight and obesity associated with micronutrient deficiency (anaemia, hypovitaminosis A) and malnutrition. Multiple stimuli to consumption of processed foods, including advertising and the cost-satiety-flavour ratio of these foods are also factors that contribute to this situation ${ }^{7-13}$. 


\section{Agricultural models and access to adequate and healthy food}

The NSA approach could be developed in quite distinct perspectives depending on existing conceptual matrices, institutional designs and political projects in each national context. This section explores analytical aspects and policy implications of these perspectives and their joint manifestation as evidenced in the Brazilian case. Burlandy et al. ${ }^{14}$ identified three of them in the international literature on the connections between nutrition and agriculture. The first perspective is a sort of combination between a biomedical, medicalized and sectoral vision that characterizes most nutrition policies - limiting nutrition to the health sector - and the 'productivist' and highly-technological models of agriculture. Another perspective is based in the concept of food regime according to which the access to adequate and healthy food has many determinants reflecting the major trends in the world food system ${ }^{15}$. This is the case of the agricultural model whose prevalent features reflect old and well-established 'productivist' views coming from the green revolution now being updated as a new green revolution. Large-scale and highly mechanized monocultures are interrelated with current trends towards monotonous and poor food diets. Systemic linkages under private logics reflect the absence of sovereign food provisioning policies.

Campbell \& Dixon ${ }^{16}$ and Friedman ${ }^{17}$ showed how ideologies of nutrition and agricultural industrialization have changed attuned with key features of food regimes with significant implications for the NSA approach. This is the case of the argument that two food regimes are in contention and running in parallel, each of them serving a different global class of consumers. The first one is based on a transnational supply chain of "quality" foods for cosmopolitan consumers across the world.

The second is based on industrial and even more chemically and genetically modified foodstuffs offered to the lowest income consumers ${ }^{17}$. This means dealing with nutrition through an industrial path, grounded in functional foods and genetic science, including practices such as fortification. Accordingly, as transnational supply chains move into the global South, both farming systems and local markets are threatened, and the growing masses of the poor, who can no longer access fresh foods, tend to increase their consumption of industrial cheaper food, most probably the least healthy and most durable commodities.

The third perspective takes an appropriate conceptualization of food and nutrition security in order to promoting a systemic approach favouring an intersectoral design of public policies coordinating food production, commercialization and consumption while valuing short food supply chains $s^{5}$. This approach leads to actions promoting both food production and provisioning and healthy food practices. The premise is that the current nutritional and food status of the Brazilian population in its relation with social inequalities are strongly conditioned by the way food has been produced and commercialized in the country. Thus, alternatives for facing priority tasks in relation to nutrition (obesity, micronutrient deficiencies, hunger and undernutrition) reside, primarily, in transforming the food production model towards agroecological models, as well as in changing the patterns of food provisioning and accessing.

In this sense, a NSA would be one that simultaneously favours: a) greater availability of fresh food produced in agroecological bases; b) social, economic and environmental sustainability; c) promotion of agrobiodiversity. Accordingly, the focus on NSA implies having a more comprehensive view of the food question involved in economic development, i.e., by taking food not only as foodstuffs (goods) but also as food habits (the ways people make use of these goods) ${ }^{18}$. The perspective proposed in this paper does not confirm but rather differs from the 'productivist' perspective, since it reframes the role of agriculture in food production by emphasizing alternative agricultural models based on family farmers. Furthermore, the role of food providers played by rural families involves also specific relationships with nature and the territory, the valuing of biological and cultural diversity and the maintenance of the social and cultural tissue, amongst others ${ }^{19-21}$.

The role of agricultural models in promoting adequate and healthy food is faced with challenges derived from the coexistence of distinct models of agriculture in Brazil, i.e "patronal agriculture" (also known as the agribusiness sector) and "family farming" (gathering a variety of social groups). According to the last Agricultural Census (2006), 4,3 millions of family farmers occupy only $24.3 \%$ of the total area, while 800 thousands patronal farms concentrates $75.7 \%$ of the area ${ }^{22}$. The coexistence of the two models is marked by complementarities, tensions and contradictions. 
Notwithstanding the socioeconomic significance of family farming and its potential to contribute to a NSA, large-scale monoculture and livestock occupy an important place in the Brazilian economy and also in the domestic food supply ${ }^{23}$. Besides promoting the degradation of nature and compromising biodiversity, land concentration is considered as one of the main causes of Brazil's well-known social inequalities. The concentration of land and other productive resources has contributed to the expansion of highly-technical agricultural models making extensive use of agrochemicals impacting the health of both rural workers and consumers ${ }^{24}$. One should add to this picture the control of food chains by large corporations, the impacts of developed countries' trade policies and the outcomes of the recent food price crises ${ }^{25,26}$.

In summary, national food provisioning policies driven by the conceptual references assumed in this paper must take into account the types of goods and the circuits through which they circulate, the models of production and the food habits they promote, price formation, moving in the reverse direction of distancing of production and consumption, bringing these two elements closer instead $^{27}$. The diversity of food habits and natural resources are important inputs to a diet rich in micronutrients which could be better promoted by decentralized food systems based on regional-local circuits of food production, distribution and consumption based on a diversified family farming. Among the advantages of such a model are: (a) access to a healthier and diversified diet with a larger amount of fresh products; (b) avoid food losses and waste; (c) use of more sustainable methods that preserve food nutritional properties; (d) lower costs of transportation and logistics, besides saving energy.

\section{Food and nutrition programmes and experiences}

Food and nutrition policies began to be implemented in the 1930s, but only in the middle of 1970 brought up, for the first time, the intention to integrate nutrition, food and agriculture ${ }^{28}$. Notwithstanding, the major step in terms of an integrated view was given by the adoption of an intersectoral and participatory focus of FNSS in the launching of Zero Hunger Program in 2003. The main innovation of the Brazilian strategy with regards to nutrition-sensitive agriculture is the articulation at local level of public spending with food assistance to the poor, to the guarantee of local markets to smallholder farmers. Based on the FNSS approach, new programmes were designed and old programmes were redesigned aimed at linking different dimensions and sectors of the food system, especially agriculture, health and education.

\section{Food Procurement Programme (PAA)}

The Food Procurement Programme (PAA) was established in 2003 by the Federal Government and it is considered an example of virtuous articulation between agricultural policy and the food and nutrition perspective. Its main objectives are: (i) to strengthen small-holder family farmers, promoting their economic and social inclusion; (ii) to encourage the consumption and recovery of foodstuffs traditionally produced by small-holder farmers; (iii) to promote regular access to food for the population in food and nutrition insecurity; (iv) to promote regular food supply; (v) to constitute public stocks of food produced by small-holder farmers; (vi) to support the constitution of stocks by cooperatives of small-holder farmers; (vii) to strengthen local and regional circuits and local marketing networks; viii) to promote and enhance biodiversity and the organic and agroecological food production, (ix) to encourage healthy eating inhabits at local and regional level; (x) to stimulate cooperatives and other forms of association ${ }^{29}$.

The government buys food directly from small-holder family farmers or their organizations, in a decentralized manner and with little bureaucracy involved. The food is distributed through social organizations to those in food insecurity or directed to compose strategic public stocks. The institutional format and the operational design of the program reflect its intersectoral perspective with a Managing Group formed by 5 Ministries of State. Various evaluations conclude that PAA has an important role in linking the dimensions of production, supply and food consumption, as well as the strengthening of small-holder farmers ${ }^{30-35}$.

The programme stimulates the diversification of food production and the conservation of biodiversity, just as much as it values regional food. Many foodstuffs of high nutritional value from Brazilian main biomes that were seriously threatened by the advance of monocultures and had little commercial value, started to be acquired with PAA. In addition, the acquisition and distribution of local varieties of seeds (traditional or creole) has helped to generate greater auton- 
omy to family farmers, and to rescue varieties of seeds that were being lost. The program pays up to $30 \%$ more to agroecological production in relation to products from conventional agriculture. Greater visibility is given to the production of rural women, strengthening their economic autonomy and self-esteem ${ }^{30}$. Nonetheless, the program still has a limited coverage ${ }^{36}$ and it efficiency also depends on dealing with challenges related to land access and territorial rights, the transition to sustainable forms of production, support for infrastructure, among others ${ }^{37}$.

\section{National School Meal Programme (PNAE)}

Greater access to healthy food and the strengthening of local family farming was also promoted by the recent remodelling and expansion of the PNAE - a programme originally launched in $1954^{38}$. Since 2003 PNAE has undergone changes in the programme-design aiming at strengthening its strategic role in promoting the SAN, such as: the establishment of guidelines for promoting healthy eating in schools; the redefinition of the criteria for the formulation of menus aiming at articulating the nutritional dimension with respect to food culture of each region and prioritization of fresh raw or semi-processed food.

In 2009, a new law established a set of a new regulation in the programme-design. One of them must be highlighted considering that it exemplifies the comprehensive approach of FNSS. Following the previous experience with PAA, the law provides for the mandatory allocation of at least $30 \%$ of the funds transferred by the federal government to states and municipalities to purchase foods directly from family farmers or their organizations ${ }^{39-41}$.

The programme offers daily around 46 million free-meals in public schools all over the country. Although most of the municipalities are meeting or exceeding the minimum percentage of local acquisition, the purchase from family farmers in big cities and metropolitan areas still represents a major challenge. It is also necessary to fit the structure of schools for the reception and proper preparation of foods ${ }^{42}$.

\section{Intersectoral Strategy against Obesity and Overweight}

A new initiative based on the FNS approach has been recently launched in Brazil is the Intersectoral Strategy for Prevention and Control of
Obesity $^{10}$. Aiming at integrating existing sectoral actions to prevent and control obesity. It has been formulated by CAISAN in consultation with the CONSEA. Obesity is considered as a multidimensional and complex phenomenon and a strategy to overcome the problem requires the adoption of healthier ways of eating and living and also changes in the food system given the close relationship between models of production, consumption patterns and nutritional aspects.

The strategy aims to increase the consumption of healthy fresh and regional foods and decrease the consumption of processed foods strengthening local circuits of food production, provisioning and consumption reinforcing the interaction between agriculture and nutrition trough several initiatives encompassing the dimensions of production, marketing, supply and consumption. Regarding the regulation and control of food quality, the main focus is on the abusive use of pesticides ${ }^{43}$.

\section{Experiences in agroecology}

In Brazil, initiatives bringing together agriculture and nutrition are not restricted to government programs and actions. Several concrete experiments in food production are gaining political expression ${ }^{44}$. This is particularly the case of experiences in agroecology. Such experiments articulate agroecological practices and FNS strategies involving a wide range of activities from the rescue and conservation of local seeds and animal breeds, the diversification of production systems to the recovering of regional food and self-consumption ${ }^{45}$.

The systemic vision of agroecology intends to articulate agricultural, ecological and socio-economic aspects, being an important way of linking agriculture and nutrition ${ }^{46-50}$. A brief review of a set of agroecological experiences in the various biomes testifies their potential in the promotion of a nutrition-sensitive agriculture involving at least three dimensions ${ }^{51}$.

First, the diversification of food production and agro-biodiversity promoted mainly through family farmers' production and mutual exchange of native-species seeds. This includes the creation of seed banks as a strategy to rescue varieties and diversify family diets as well as to resist to technological standards imposed by corporations and the agribusiness model. Secondly, food cultures rescue and the promotion of nutritional education and consumption with a special role played by women groups. Thirdly, the building up of new 
relations with markets which is considered a strategic component to the extent that agroecological markets narrow the links between producers and consumers, representing educational spaces to exchange knowledge and food culture ${ }^{52}$.

In relation to public policies, a recent achievement has been the institution, in 2012, of a National Policy on Agroecology and Organic Production (PNAPO) aimed at integrating, articulating and adjusting programmes and actions that promote agroecological transition and organic production with the view of contributing to the provision and consumption of healthy food. In 2013, a Brazilian Agroecological Plan has been launched with the goal of articulating a group of more than 100 initiatives under the responsibility of 14 Ministries aimed at stimulating the agroecological transition. So far, there is no available data of its impacts on the agroecological production.

\section{Bio-fortification as a distinctive approach}

In 2003, the Brazilian state-owned company Agricultural Research Corporation (EMBRAPA) launched the Biofort Project - Agricultural Products Bio-fortification for Human Nutrition. The project is based on partnership with HarvestPlus and AgroSalud, a research consortium integrating countries in Latin America, Africa and Asia, funded by Bill and Melinda Gates Foundation, the World Bank and international development agencies.

Bio-fortification of seeds consists in a process of crossbreeding plants of the same species, with the objective of generating more nutritious seeds. This process can be done through conventional techniques, selective breeding or genetic engineering. Internationally, bio-fortification is being propagated as an innovative strategy to deal with micronutrients deficiencies and hidden hunger in developing countries ${ }^{53}$. Researchers linked to Biofort and HarvestPlus argue that the diet of the population in developing countries is based on large quantities of staple foods (corn, wheat and rice) with few high nutritional value foodstuffs (fruits, vegetables and meat). Thus, bio-fortification is proposed as the short term solution for overcoming vitamins and minerals deficits while taking the "definitive solution" through diet diversification (increasing red meats, fish, fruits, greens and vegetables) as a more expensive long-term goal ${ }^{54,55}$. Supporters of the approach argue that bio-fortifications is an evolution when compared to the fortification of processed food, especially when it comes to the rural poor. This is due to the unavailability of nutritionally enriched industrial food at local markets combined with the inefficiency of public health systems in rural areas to implement micronutrients supplementation.

In 2011, the project started to establish bilateral partnerships with municipal governments providing bio-fortified seeds to be donated to smallholder farmers, which in turn should commit themselves to sell their production to supply meals at municipal public schools $s^{56}$. So far, there is no evaluation available of the outcomes of this initiative.

\section{Lessons learned from the Brazilian experience}

The Brazilian experience suggests the enormous potential of adopting the approach on FNSS as described in this paper for promoting a nutrition-sensitive agriculture. The main argument is that for promoting FNSS policies must be intersectoral, decentralized and framed in order to allow for institutional coordination. It has been also argued that these are requirements for setting in place integrated actions aimed at a nutrition-sensitive agriculture through the coordination of numerous Ministries, agencies and social actors committed to the eradication of hunger and the promotion of sustainable rural development.

This implies the making and implementing of intersectoral programmes and actions that contribute to: i) strengthening local circuits of food production, provisioning and consumption; ii) changing the production matrix towards sustainable and diversified systems of food production; iii) agrobiodiversity conservation, recovering and valuing; iv) increasing access by food and nutrition insecure groups to fresh and regional foodstuffs, especially fruits, greens and vegetables.

Amongst the programs and actions that dialogue with the concept of nutrition-sensitive agriculture, we brought for discussion the PAA, PNAE, Plan to Overcome Overweight and Obesity, Experiences in Agroecology and the Project on Bio-fortification.

The programs based on an integrative way to prioritize the commercialization of fresh foods, especially from family farming, valuing agroecological production and biodiversity. The government, through their institutions (schools, hospitals, etc.), is a strategic actor in the food market. 
Their criteria for food purchasing, including decisions on the kind of food to purchase and from whom, can affect the position of the different producers in the market and impact local and regional economies.

Despite the successful outcomes some important challenges have been also highlighted, such as: the production and marketing conditions for family farmers; food transformation parameters imposed by industries and advertisement campaigns; the reduction of biodiversity and the correspondent decreasing food diversity that is crucial for healthy food practices; the trends towards higher levels of overweight and obesity. One should also point out to the tensions and contradictions between policies aimed at promoting FNSS, as the ones highlighted in this paper, and the prevalent models of food production and consumption as represented by largescale and intensively mechanized monocultures making extensive use of chemical products (pesticides and fertilizers) and GMO's.

Family farming could keep on playing a role in this scenario as part of the solution for promoting more equitable, sustainable and healthy models if adequately supported. Notwithstanding, this is a complex task considering that the coexistence of agricultural models (family farming and patronal agriculture or the agribusiness sector) implies competing values, power imbalances and distinct institutional frameworks, some of them reflecting prevailing trends at global level.

A process with multiple determinants such as promoting an intersectoral approach of FNSS demands integrative solutions and the convergence of different types of actions such as: (a) promoting and stimulating adequate food habits; (b) guaranteeing universal access to adequate food and meals; (d) regulating and controlling the composition and advertising of processed food; (e) assuring quality in food production by valuing agroecology, organic production, biodiversity and the diversity of cultures and livelihoods.

Specific reference should be made to the Brazilian experience on biofortification as represented by the Biofort Project. Although it is presented as a strategy for FNS, the project is mostly developed in a separate path and has no significant connection with the intersectoral and systemic approach underling the National System and Policy for FNS. There is also the risk of the bio-fortification approach ending up reinforcing the corporate control over seed markets that jeopardizes small-holder family farmers' autonomy. As it is not disconnects with the 'green revolution' technological package, questions are also raised about on is relationship with transgenesis and the use of agro-chemicals. In any case, there is the lack of regulation on this technique although it is being implemented for some years now.

Finally, one should point out some elements involved in the promotion of the concept and practice of a nutrition-sensitive agriculture, especially in the Brazilian context. First, the advantages of family farming for food diversification and for increasing access to an affordable and better nutritional food basket for families. Secondly, strengthening agricultural systems aimed at valuing biodiversity, peasant livelihoods and product diversification through agroecological production, biome-specific seed improvements by smallholder farmers, preserving food culture and adequate rural extension services. Thirdly, considering seeds at the heart of country's and local community's food sovereignty, which implies democratizing the access to seeds and technologies, as well as an opening debate on the socioeconomic and nutritional meanings and implications of the bio-fortification of seeds. Fourthly, narrowing the circuits of food production and consumption in the view of comparative advantages of the regional and local systems of food production and provisioning. Finally, be attentive to new conjectural and structural contexts such as volatile and high international food prices and the effects of climate change and extreme events.

Each initiative and action towards a nutrition-sensitive agriculture that could be promoted in Brazil should be subject to "public scrutiny". What is the social context that justifies the initiative? What is the time horizon of public policy? Public interests committed to common goods and collective action are the priority in the initiatives, or the initiatives are favouring ownership groups and special interests? The exercise of reflecting on this subject will bring to light a large set of variables related to the reasons and needs for this specific approach. 


\section{Collaborations}

All authors participated in the conception, design and analysis of the Brazilian case study coordinated by RS Maluf, that was linked to an international research project on the topic nutrition-sensitive agriculture. L Burlandy, M Santarelli, V Schottz and JS Speranza also participated in the writing and critical review of the manuscript and approved the final version to be published.

\section{References}

1. Pinstrup-Andersen P. Making Food Systems Nutrition-Sensitive: An Economic Policy Perspective. World Food Policy 2014; 1(1):72-93.

2. Maluf RS. Segurança alimentar e nutricional. Petrópolis: Ed. Vozes; 2007.

3. Burlandy L. Construção da Política de Segurança Alimentar e Nutricional no Brasil: estratégias e desafios para promoção da intersetorialidade no nível federal de governo. Cien Saude Colet 2009; 14(1):851-860.

4. Burlandy L. A atuação da sociedade civil no campo da alimentação e nutrição no Brasil: elementos para reflexão. Cien Saude Colet 2011; 1(1):3064-3077.

5. Burlandy L, Rocha C, Maluf RS. Integrating nutrition into agricultural and rural development policies - the Brazilian experience of building an innovative food and nutrition security approach. In: FAO. Improving diets and nutrition - food-based approaches. Rome, Oxfordshire: CABI, FAO; 2014. v.1. p. 101-112.

6. Leão M, Maluf RS. Effective public policies and active citizenship - Brazil's experience of building a Food and Nutrition Security System. Brasília: ABRANDH/OXFAM; 2012.

7. Instituto de Pesquisa Econômica Aplicada (IPEA). $\mathrm{Ob}$ jetivos de Desenvolvimento do Milênio - Relatório $\mathrm{Na}$ cional de Acompanhamento. Brasília: IPEA; 2010.

8. Conselho Nacional de Segurança Alimentar e Nutricional (CONSEA). A Segurança Alimentar e Nutricional e o Direito Humano à Alimentação Adequada no Brasil. Brasília (DF): CONSEA; 2010.

9. Instituto Brasileiro de Geografia e Estatística (IBGE). Pesquisa Nacional por Amostra de Domicílio (PNAD)Segurança alimentar - 2004/2010. Rio de Janeiro: IBGE; 2010.

10. Brasil. Ministério do Desenvolvimento Social (MS). Câmara Interministerial de Segurança Alimentar e Nutricional (CAISAN). Estratégia Intersetorial de prevenção e controle da obesidade: recomendações para estados e municípios. Brasília: CAISAN/MDS; 2012.

11. Henriques P, Sally EF, Burlandy L, Beiler RM. Regulamentação da propaganda de alimentos infantis como estratégia para a promoção da saúde. Cien Saude Colet 2012; 17(1):481-490.

12. Henriques P, Dias PC, Burlandy L. A regulamentação da propaganda de alimentos no Brasil: convergências e conflitos de interesses. Cad Saude Publica 2014; 30(6):1219-1228.

13. Monteiro CA, Levy RB, Claro RM, Castro IRR, Cannon G. Increasing consumption of ultra-processed foods and likely impact on human health: evidence from Brazil. Public Health Nutr 2011; 14(01):5-13.

14. Burlandy L, Bocca C, Mattos R. Mediações entre conceitos, conhecimento e políticas de alimentação, nutrição e segurança alimentar e nutricional. Rev Nutr 2012; 25(1):9-20.

15. McMichael P. A food regime analysis of the 'world food crises'. Agric Human Values 2009; 26(4):281-295.

16. Campbell H, Dixon J. Introduction to the special symposium: reflecting on twenty years of the food regimes approach in agri-food studies. Agric Human Values 2009; 26(4):261-265.

17. Friedman H. Discussion: moving food regimes forward: reflections on symposium essays. Agric Human Values 2009; 26(4):335-344. 
18. Maluf RS. Economic development and the food question in Latin America. Food Policy 1998; 2(23):155-172.

19. Carneiro MJ, Maluf RS. Para além da produção - multifuncionalidade e agricultura familiar. Rio de Janeiro: Mauad; 2003.

20. Cazella AA, Bonnal P, Maluf RS. Agricultura familiar - multifuncionalidade e desenvolvimento territorial no Brasil. Rio de Janeiro: Mauad; 2009.

21. Wilkins JL. Civic dietetics: opportunities for integrating civic agriculture concepts into dietetic practice. $\mathrm{Ag}$ ric Human Values 2009; 26:57-66.

22. Instituto Brasileiro de Geografia e Estatística (IBGE). Censo Agropecuário. Rio de Janeiro: IBGE; 2006.

23. Carneiro FF, Pignati W, Rigotto RM, Augusto LGS, Rizollo A, Muller N M, Alexandre VP, Friedrich K, Mello MS. Dossiê Abrasco - um alerta sobre os impactos dos agrotóxicos na saúde. Rio de Janeiro: Abrasco; 2012.

24. Preza DLC, Augusto LGS. Vulnerabilidades de trabalhadores rurais frente ao uso de agrotóxicos na produção de hortaliças em região do Nordeste do Brasil. Rev Bras Saúde Ocup 2012; 37(125):89-98.

25. High Level Panel of Experts on Food Security and Nutrition of the Committee on World Food Security (HLPE). Price volatility and food security. A report by the HLPE. Rome: Committee on World Food Security/ HLPE; 2011. [cited 2013 Jun 5]: [about 79 p]. Available from: http://www.fao.org/cfs/cfs-hlpe

26. Ploeg JD. Peasant-driven agricultural growth and food sovereignty, The Journal of Peasant Studies 2014; 41(6):999-1030.

27. Delgado NG, Leite SP. Políticas de desenvolvimento territorial no meio rural brasileiro: novas institucionalidades e protagonismo dos atores. Dados 2011; 54(2):431-473.

28. Peliano A. Lições da História: Avanços e Retrocessos na Trajetória das Políticas de Combate à Fome e à Pobreza no Brasil. In: Aranha A, organizadores. Fome Zero: uma história brasileira. Brasília: Ministério do Desenvolvimento Social; 2010. p. 26-41.

29. Brasil. 3o Seminário Nacional do Programa de Aquisição de Alimentos-PAA - Caderno de Texto. Brasília: Ministério do Desenvolvimento Social; 2010.

30. Cordeiro A. Resultados do programa de aquisição de alimentos - PAA: a perspectiva dos beneficiários. Brasília: CONAB; 2007.

31. Departamento de Estudos Sócio-econômicos Rurais (DESER). O Programa de Aquisição de Alimentos e sua relação com a Política Nacional de Segurança Alimentar e Nutricional e a Política de Comercialização Agrícola no Brasil, entre 2003-07: uma avaliação. Curitiba: DESER; 2008.

32. Deves, OD, Rambo AG, Filippi EE. A dinâmica das políticas públicas e das organizações locais em processos de desenvolvimento rural: o caso do programa de aquisição de alimentos no município de São Pedro do Butiá. In: Anais do $48^{\circ}$ Congresso da Sociedade Brasileira de Economia, Administração e Sociologia Rural; 2009; Porto Alegre. p. 1-20.
33. Grisa C, Schmitt CJ, Mattei LF, Maluf RS, Leite SP. Brazil's PAA: policy-driven food system. Farming Matters [serial on the internet] 2011 sep [cited 2013 Jun 15]; 1: [about 3 p.]. Avaiable from http://www.agriculturesnetwork.org/magazines/global/regional-food-systems/ brazil-paa

34. Brasil. Companhia Nacional de Abastecimento (CONAB). Total de produtos comercializados pelo PAA nos anos de 2009 a 2011. Brasília: CONAB; 2012.

35. Brasil. Ministério do Meio Ambiente (MMA). Bioma Caatinga: contexto, características e estratégias de conservação [homepage na internet]. [acessado 2013 jul 17]. Disponível em: http://www.mma.gov.br/biomas/ caatinga/item/191

36. Brasil. Ministério do Desenvolvimento Social e Combate à Fome (MDS). $3^{\circ}$ Seminário Nacional do Programa de Aquisição de Alimentos - PAA - relatório técnico e analítico. Brasília: MDS; 2010.

37. Conselho Nacional de Segurança Alimentar e Nutricional (CONSEA). Programa de aquisição de alimentos da agricultura familiar. Cinco anos. Balanços e perspectivas. Brasília: CONSEA; 2008.

38. Brasil. Fundo Nacional de Desenvolvimento da Educação (FNDE). Programa Nacional de Alimentação Escolar. Encontro Nacional de Nutricionistas do Programa Nacional de Alimentação Escolar da Região Norte. Brasília: FNDE; 2013.

39. Brasil. Lei ${ }^{\circ} 11.947$ de 16 de Junho de 2009. Dispõe sobre o atendimento da alimentação escolar e do Programa Dinheiro Direto na Escola aos alunos da educação básica; altera as Leis nos 10.880 , de 9 de junho de 2004, 11.273 , de 6 de fevereiro de 2006, 11.507, de 20 de julho de 2007; revoga dispositivos da Medida Provisória no 2.178-36, de 24 de agosto de 2001, e a Lei no 8.913 , de 12 de julho de 1994; e dá outras providências. Diário Oficial da União 2009; 17 jun.

40. Brasil. Fundo Nacional de Desenvolvimento da Educação (FNDE). Resolução no 38 de 16 de Julho de 2009. Dispõe sobre o atendimento da alimentação escolar aos alunos da educação básica no Programa Nacional de Alimentação Escolar - PNAE. Diário Oficial da União $2009 ; 17$ jul.

41. Sidaner E, Balaban D, Burlandy L. The Brazilian school feeding programme: an example of an integrated programme in support of food and nutrition security. Public Health Nutr 2013; 16(6):989-994.

42. Saraiva EB, Silva AF, Souza AA, Cerqueira G, Chagas CMS, Toral N. Panorama da compra de alimentos da agricultura familiar para o Programa Nacional de Alimentação Escolar. Cien Saude Colet 2013; 18(4):927936.

43. Agência Nacional de Vigilância Sanitária (ANVISA). Programa de Análise de Resíduo de Agrotóxico em Alimentos (PARA), dados da coleta e análise de alimentos de 2010. Brasília: ANVISA; 2011.

44. Almeida SG. Construção e desafios do campo agroecológico brasileiro. In: Petersen P, organizador. Agricultura familiar camponesa na construção do futuro. Rio de Janeiro: ASPTA; 2009. p. 67-83. 
45. Perez-Cassarino J. Agroecologia, mercados e sistemas agroalimentares: uma leitura a partir da Soberania e Segurança Alimentar e Nutricional. In: Gomes, JCC, Assis WS, organizadores. Agroecologia: princípios e reflexões conceituais. Brasília: Embrapa; 2013. p.181-230.

46. Gliessman SR. Agroecologia: processos ecológicos em agricultura sustentável. Porto Alegre: UFRGS; 2000.

47. Petersen P, Dal Soglio FK, Caporal FR. A construção de uma ciência a serviço do campesinato. In: Petersen P, organizador. Agricultura Familiar Camponesa na construção do futuro. Rio de Janeiro: ASPTA; 2009. p. 85-103.

48. Azevedo E, Pelicioni MCF. Promoção da Saúde, Sustentabilidade e Agroecologia: uma discussão intersetorial. Saúde Soc 2011; 20(3):715-729.

49. Schutter O. Agroecology and the Right to Food. Geneva. Report presented at the 16th Session of the United Nations Human Rights Council - A/HRC/16/49 [internet] 2010 [cited 2013 Aug 02]: [about 21 p.]. Available from: http://www.srfood.org/images/stories/ pdf/officialreports/20110308_a-hrc-16-49_agroecology_en.pdf

50. Padula J, Cardoso IM, Ferrari EA, Dal Soglio FK. Os caminhos da agroecologia no Brasil. In: Gomes JCC, Assis WS, organizadores. Agroecologia: princípios e reflexões conceituais. Brasília: Embrapa; 2013. p. 37-73.

51. Articulação Nacional de Agroecologia (ANA). Grupo de Trabalho de Soberania e Segurança Alimentar (GT SSA). Soberania e Segurança Alimentar na construção da agroecologia: sistematização de experiências. Rio de Janeiro: ANA/GT SSA; 2010.

52. Reis MR. Tecnologia social de produção de sementes e agrobiodiversidade [tese]. Brasília: Universidade de Brasília/CDS; 2012.

53. Gomes FS. Artificial mends to food systems. In: Dederichs-Bain B, Ramm W, editors. Food fortification: a techno-fix or a sustainable solution to fight hidden hunger? Bonn: Deutsche Welthungerhilfe \& Terre des Hommes; 2014. p. 57-60.

54. Carvalho JLV, Nutti M. Biofortificação de produtos agrícolas para nutrição humana. In: Anais da $64^{a}$ Reunião da Sociedade Brasileira para o Progresso da Ciência; 2012; São Luiz. p. 1-3.

55. Nutti M. A história dos projetos HarvestPlus, AgroSalud e BioFort no Brasil. IV Reunião de Biofortificação [artigo na internet] 2011 [acessado 2013 jul 17]: [cerca de 12 p.]. Disponível em: http://ainfo.cnptia.embrapa.br/ digital/bitstream/item/54482/1/2011-133.pdf

56. Coelho JB, Fontes MO. A Experiência do cultivo de alimentos biofortificados no município de Itaguai (RJ). IV Reunião de Biofortificação [artigo na internet] 2011 [acessado 2013 jul 17]: [cerca de 4 p.]. Disponível em: http://biofort.com.br/index.php?option=com_phocadownload\&view $=$ category\&download $=178$ :aptt301220121456 cf\&id=30:pub-transftecnologia\&Ite$\operatorname{mid}=111$.

Artigo apresentado em 18/09/2014

Aprovado em 24/11/2014

Versão final apresentada em 26/11/2014 